\title{
The Metabolic Stability of Carbohydrates in Walls of Hyphae of Aspergillus clavatus
}

\author{
By D. L. CORINA AND K. A. MUNDAY \\ Department of Physiology and Biochemistry, The University of Southampton, \\ Southampton, $\mathrm{SO}_{9} \mathrm{NH}_{\mathrm{NH}}$
}

(Accepted for publication I6 December 1970)

\section{SUMMARY}

The metabolic stability of carbohydrates in walls of hyphae of Aspergillus clavatus was investigated through measurements of mycelial isotope distribution from $\left[\mathrm{U}^{14} \mathrm{C}\right]$ glucose and the ${ }^{3} \mathrm{H} /{ }^{14} \mathrm{C}$ ratios of re-isolated monosaccharides, when the organism was grown on labelled glucose as sole carbon source. The results suggest that glucose and glucosamine became metabolically inert once they had been incorporated into the wall polymers, and that the biosynthesis of glucosamine and its incorporation into the cell wall as $N$-acetylglucosamine were direct processes not subject to metabolic randomization at the precursor level.

\section{INTRODUCTION}

The normal mode of vegetative growth in mycelial fungi, hyphal extension by apical growth (Smith, 1933; Zalokar, 1959), raises the question of whether the polysaccharides of the hyphal wall are metabolically inert or capable of significant exchange with the monomers of the cytoplasm. That the probable main site of wall biosynthesis is at a specific growing point (Marchant, Peat \& Banbury, 1967; Bartnicki-Garcia \& Lippman, 1969) suggests that there may be little subsequent re-utilization of wall polysaccharides. It was therefore of interest to determine the stability and metabolic contribution of the hyphal wall in relation to the utilization of carbohydrate in Aspergillus clavatus during vegetative growth.

\section{METHODS}

Materials. $\left[\mathrm{U}^{14} \mathrm{C}\right]$ Glucose and $\left[6-{ }^{3} \mathrm{H}\right]$ glucose were purchased from The Radiochemical Centre (Amersham, Buckinghamshire), and other reagents from British Drug Houses Ltd (Poole, Dorset).

Organism and culture. Aspergillus clavatus was grown in submerged culture in liquid media of the following composition (g./l. distilled water): $\mathrm{NaNO}_{3}, 3 \cdot 0 ; \mathrm{K}_{2} \mathrm{HPO}_{4}$, $2.0 ; \mathrm{KH}_{2} \mathrm{PO}_{4}, 0.5 ; \mathrm{KCl}, 0.5 ; \mathrm{MgSO}_{4} .7 \mathrm{H}_{2} \mathrm{O}, 0.5 ; \mathrm{FeSO}_{4} .7 \mathrm{H}_{2} \mathrm{O}, 0.01$; glucose, from $\mathrm{I} \cdot \mathrm{O}$ to 30 ; and incubated for up to 9 days in shake-flask culture at $27^{\circ}$ from an inoculum (I to $2 \% \mathrm{v}$./v.) of conidial suspension. It grew in the form of small spherical mycelial clumps, 10 to $20 / \mathrm{ml}$. The number of clumps remained constant but their size increased during growth.

Mycelial clumps were pulse-labelled with radioactive glucose between 24 and $48 \mathrm{~h}$., the initial period of exponential growth, as detailed in Tables $\mathrm{I}$ to 3 . Five or ro $\mathrm{ml}$. samples of cultures were withdrawn at various times post-pulse and assayed for radioactivity. 
Carbohydrate composition of wall. Glucose and $N$-acetylglucosamine in the hyphal wall, determined by ${ }^{14} \mathrm{C}$ isotope distribution (Troy \& Koffler, 1969), constituted $48 \%(\mathrm{w} / \mathrm{w})$ and $23 \%$ respectively. These monosaccharides were taken as representative of all wall carbohydrates. The subsequent use of the word glucosamine denotes both free glucosamine and cell wall $N$-acetylglucosamine which is deacylated on acid hydrolysis.

Preparation of mycelial fractions for assay of radioactivity. Mycelial clumps (50 to I00) were harvested by filtration, washed briefly, resuspended in 8 vol. of $0.154 \mathrm{M}-\mathrm{KCl}$ and disrupted by ultrasonic disintegration for $40 \mathrm{~min}$. at $20 \mathrm{KHz}$, with cooling. Hyphal walls were isolated from the sonicated preparation by the mechanical method of Aronson \& Machlis (1959) and washed until washings were free from radioactivity. Whole mycelial clumps and walls were solubilized by hydrolysis with $6 \mathrm{~N}-\mathrm{HCl}$ at $110^{\circ}$ for $16 \mathrm{~h}$. Excess acid was removed in vacuo and the hydrolysates were neutralized before determining total radioactivity in aqueous solutions.

Hexose extraction. Glucose from the culture medium, wall hydrolysates and the deproteinized supernatant of centrifuged (100,000 $g$ for $I \mathrm{~h}$.) sonicated mycelia, was purified by deionization with Amberlite MB I ion-exchange resin followed by paper chromatography, with $5 \mathrm{mg}$. carrier, on Whatman $3 \mathrm{MM}$ paper using methyl ethyl ketone-acetic acid-water saturated with boric acid ( $9: \mathrm{I}: \mathrm{I}$, by vol.) as solvent. Glucosamine from wall hydrolysates and sonicate supernatants was purified with Amberlite IRA $400\left(\mathrm{CO}_{3}^{2+}\right.$ form) resin followed by chromatography as the hydrochloride using butan-I-ol-pyridine-water (6:4:3, by vol.) as solvent. The corresponding sample areas were eluted and the radioactivity determined.

Formaldehyde-dimedone complex. Carbon-6 of re-isolated glucosamine was isolated after periodate oxidation as the dimedone derivative (Barnett \& Corina, I966).

Radioactivity determinations. Aqueous solutions ( 0.1 to $0.5 \mathrm{ml}$.) were added to $10 \mathrm{ml}$. of NE 220 scintillation fluid (Nuclear Enterprises Ltd, Edinburgh) and counted by liquid scintillation spectrometry. Counts were corrected for quenching and, in ${ }^{3} \mathrm{H} /{ }^{14} \mathrm{C}$ ratio experiments, for crossover between ${ }^{3} \mathrm{H}$ and ${ }^{14} \mathrm{C}$ channels. Formaldehydedimedone complexes were counted directly as solutions in scintillation fluid.

\section{RESULTS}

${ }^{3} \mathrm{H} /{ }^{14} \mathrm{C}$ Isotope ratios of re-isolated glucose and glucosamine. Cultures pulse-labelled with $\left[\mathrm{U}^{14} \mathrm{C}\right]$ glucose retained a constant proportion of the label initially incorporated into whole mycelia and all the label initially incorporated into the hyphal wall (Table I). The high level of ${ }^{14} \mathrm{C}$ retention by the mycelium prompted the use of mixed-labelled $\left[{ }^{14} \mathrm{C},{ }^{3} \mathrm{H}\right]$ glucose further to evaluate the stability of wall carbohydrate. As the hydrogens of glucose are metabolically more labile than the carbon skeleton, changes in carbohydrate ${ }^{3} \mathrm{H} /{ }^{14} \mathrm{C}$ ratios provide sensitive measurements of molecular turnover (Dunn, Chenoweth \& Schaeffer, 1967).

After pulse-labelling mycelia with $\left[\mathrm{U}^{14} \mathrm{C}, 6^{3} \mathrm{H}\right]$ glucose, the ${ }^{3} \mathrm{H} /{ }^{14} \mathrm{C}$ ratios of glucose and glucosamine re-isolated from the wall were compared with the ${ }^{3} \mathrm{H} /{ }^{14} \mathrm{C}$ ratios of the free sugars re-isolated from the cytoplasm (Table 2 ). The ${ }^{3} \mathrm{H} /{ }^{14} \mathrm{C}$ ratios of wall monomers showed a high stability of ${ }^{3} \mathrm{H} /{ }^{14} \mathrm{C}$ ratios between 2 and 7 days after the pulse. In contrast, the ratios in the free cytoplasmic sugars showed a significant lowering of the ${ }^{3} \mathrm{H} /{ }^{14} \mathrm{C}$ ratios due to randomization and a higher metabolic loss of tritium over carbon. 
Table I. Retention of ${ }^{14} \mathrm{C}$ label by whole mycelium and hyphal wall fraction of Aspergillus clavatus after pulse-labelling

Mycelial clumps pulse-labelled in $15 \mathrm{~g}$. [ $\left.\mathrm{U}^{14} \mathrm{C}\right]$ glucose $/ 1 .+$ salts medium, transferred postpulse day 0 to 3 to $20 \mathrm{~g}$. unlabelled glucose $/ 1$. + salts, day 3 to $1 \cdot 0 \mathrm{~g}$. glucose $/ \mathrm{l}$. + salts. Radioactivity measured in acid-solubilized mycelia and walls, counts corrected to constant culture volume at end of pulse $(50 \mathrm{ml}$.).

$\begin{array}{ccc}\begin{array}{c}\text { Days } \\ \text { post-pulse }\end{array} & \text { Whole mycelium } & \text { Cell wall } \\ 0 & 1039 & 355 \\ 1 & 700 & 320 \\ 2 & 712 & 315 \\ 5 & 675 & 398\end{array}$

Table $2 .{ }^{3} \mathrm{H} /{ }^{14} \mathrm{C}$ ratios of glucose and glucosamine re-isolated from walls and cytoplasm of hyphae of Aspergillus clavatus after pulse-labelling

Mycelia pulse-labelled $24 \mathrm{~h}$. in $15 \mathrm{~g}$. [ $\mathrm{U}^{14} \mathrm{C}, 6^{3} \mathrm{H}$ ]glucose/l. + salts medium, transferred post-pulse to either $30 \mathrm{~g}$. unlabelled glucose $/ \mathrm{l}$. (series $\mathrm{A}$ ) or $10 \mathrm{~g}$. unlabelled glucose/l. (series B), plus salts.

\begin{tabular}{|c|c|c|c|c|c|c|}
\hline & & & ${ }^{3} \mathrm{H} /{ }^{1}$ & ios & & \\
\hline & & & & & & \\
\hline & & & & & Glu & ine \\
\hline post-pulse & Walls & Cyt. & Walls & Cyt. & Walls & Cyt. \\
\hline 0 & $2 \cdot 8 I$ & $3 \cdot 25$ & $9 \cdot 22$ & $6 \cdot 60$ & $9 \cdot 50$ & $8 \cdot 79$ \\
\hline I & $2 \cdot 68$ & $2 \cdot 44$ & $7 \cdot 10$ & $4 \cdot 73$ & 8.45 & 8.07 \\
\hline 2 & $2 \cdot 72$ & $I \cdot 2 I$ & $6 \cdot 40$ & 4.00 & $8 \cdot 26$ & * \\
\hline 3 & $2 \cdot 66$ & 0.79 & - & - & - & - \\
\hline 5 & $2 \cdot 57$ & 0.34 & $6 \cdot 70$ & $2 \cdot 56$ & $7 \cdot 10$ & $*$ \\
\hline 7 & - & - & $6 \cdot 10$ & $1 \cdot 44$ & 7.50 & $*$ \\
\hline
\end{tabular}

Initial $3 \cdot 50$

Final 3.00
Pulse ${ }^{3} \mathrm{H} /{ }^{14} \mathrm{C}$ ratio

Initial I · 45

Final $7 \cdot 70$

* Denotes counts not significantly above background; - denotes no samples taken at these times.

Table $3 .{ }^{3} \mathrm{H} /{ }^{14} \mathrm{C}$ ratios of formaldehyde derived from glucosamine carbon- 6

Formaldehyde-dimedone complex isolated from glucosamine

(Table 2, series B) after periodate oxidation.

\begin{tabular}{|c|c|c|}
\hline \multirow{2}{*}{$\begin{array}{c}\text { Days } \\
\text { post-pulse }\end{array}$} & \multicolumn{2}{|c|}{$\begin{array}{c}{ }^{{ }^{3} \mathrm{H} /{ }^{\mathbf{1 4}} \mathrm{C} \text { ratio }} \\
\text { Carbon-6 of glucosamine fro }\end{array}$} \\
\hline & Wall & Cyt. \\
\hline 0 & 20.0 & $35^{\circ} 0$ \\
\hline I & $17 \cdot 4$ & $5 \cdot 40$ \\
\hline 2 & $15 \cdot 2$ & \\
\hline 5 & I5.8 & * \\
\hline 7 & 14.9 & $*$ \\
\hline
\end{tabular}

* Denotes counts not significantly above background. 
On the basis of counts recovered, the lowering of the wall component ${ }^{3} \mathrm{H} /{ }^{14} \mathrm{C}$ ratios in the first 2 days could be accounted for by incorporation into the wall of residual labelled precursors. Such incorporation became insignificant after the second day because of rapid dilution of this radioactive pool. Differences in the ratio changes between series A and B (Table 2) were attributed to effects of different post-pulse glucose concentrations, while the differences in ${ }^{3} \mathrm{H} /{ }^{14} \mathrm{C}$ ratios between glucose and glucosamine do not affect the significance of the conclusions to be drawn from the stabilities of the ${ }^{3} \mathrm{H} /{ }^{14} \mathrm{C}$ ratio.

${ }^{3} \mathrm{H} /{ }^{14} \mathrm{C}$ ratios at carbon- 6 of re-isolated glucosamine. Table 3 shows the relative retention of tritium at carbon- 6 of re-isolated glucosamines, in which the ${ }^{3} \mathrm{H} /{ }^{14} \mathrm{C}$ values for C-6 of cell wall glucosamine closely parallel the ratios in the complete molecule.

\section{DISCUSSION}

Biosynthesis of the predominantly carbohydrate hyphal wall represents a major utilization of carbon source, and its influence needs to be accounted for in studies of carbohydrate metabolism in whole mycelia. Because the ${ }^{3} \mathrm{H} /{ }^{14} \mathrm{C}$ ratios of the wall components investigated were stable after initial dilution by incorporation of residual labelled precursors and no further equilibration with the cytoplasm took place, the wall, once formed, can be considered to have no further involvement in cytoplasmic carbohydrate metabolism during the 7 day post-pulse growth period studied. No autolysis was detected during the experimental period, and it is probable that there is little, if any, significant breakdown of mycelial walls until a very advanced stage of autolysis (Trinci \& Righelato, 1970).

Comparison of the ${ }^{3} \mathrm{H} /{ }^{14} \mathrm{C}$ ratios of glucose and glucosamine from walls (Table 2) also shows that both the formation of glucosamine and its subsequent incorporation into the wall were direct processes with little randomization of tritium. In bacteria, glucosamine is known to be incorporated from glucose into the wall with minimal carbon skeleton rearrangement (Shuster \& Betts, 1969).

It is, however, of considerable interest to compare this stability of carbohydrates in the hyphal walls of fungi with the recent observations of Mauck \& Glaser (1970), who observed a rapid turnover of mucopeptides and teichoic acids in bacterial walls.

The authors wish to thank the Lord Rank Research Centre for financial support.

\section{REFERENCES}

Aronson, J. M. \& Machlis, L. (1959). The chemical composition of the hyphal walls of the fungus Allomyces. American Journal of Botany 46, 292-300.

BarnetT, J. E. G. \& Corina, D. L. (1966). A synthesis of glucose-5t and glucose-5t 6-phosphate. Carbohydrate Research 3, $134-137$.

BARTNICKI-Garcia, S. \& LIPPMAN, E. (1969). Fungal morphogenesis: cell wall construction in Mucor rouxii. Science, New York $165,302-304$.

Dunn, A., Chenoweth, N. \& Schaeffer, L. D. (1967). Estimation of glucose turnover and the Cori cycle using glucose-6t, ${ }^{14} \mathrm{C}$. Biochemistry 6, 6-11.

MAUCK, J. \& GLASER, L. (1970). Turnover of the cell wall of Bacillus subtilis w-23 during logarithmic growth. Biochemical and Biophysical Research Communications 39, 699-706.

Marchant, R., Peat, A. \& Banbury, G. H. (1967). The ultrastructural basis of hyphal growth. New Phytologist 66, 623-629. 
Shuster, C. W. \& BetTs, J. (1969). Biosynthesis of amino sugars by Pseudomonas saccharophila. Journal of Bacteriology xoo, 156-16I.

Smrrh, J. H. (1933). On apical growth of fungal hyphae. Annals of Botany 37, 341-343.

Trinci, A. P. J. \& Righelato, R. C. (1970). Changes in constituents and ultrastructure of hyphal compartments during autolysis of glucose-starved Penicillium chrysogenum. Journal of General Microbiology 60, 239-249.

Troy, F. A. \& Koffler, H. (1969). The chemistry and molecular architecture of the cell walls of Penicillium chrysogenum. Journal of Biological Chemistry 244, 5563-5576.

ZaloKAR, M. (1959). Growth and differentiation of Neurospora hyphae. American Journal of Botany 46, 602-610. 